\title{
James Baldwin and the Question of Privacy: A Roundtable Conversation at the 2014 American Studies Convention
}

\author{
Brian Norman Loyola University, Maryland
}

\begin{abstract}
Six key Baldwin scholars converged at the 2014 American Studies Association to consider the question of privacy, informed by their own book-length projects in process. Key topics included Baldwin's sexuality and the (open) secret, historical lack of access to privacy in African-American experience, obligations for public representation in African-American literary history, Baldwin's attempts to construct home spaces, public access to Baldwin's private documents, and ethical matters for scholars in creating and preserving Baldwin's legacy, including his final home in St. Paul-de-Vence.
\end{abstract}

Keywords: privacy, sexuality, home, public legacy, black memory

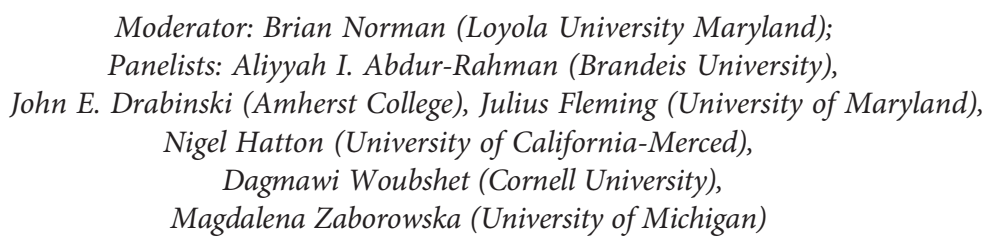

Scholars convened at the annual meeting of the American Studies Association in Los Angeles, C.A., in November 2014 to take up a longstanding concern in Baldwin Studies: the question of privacy.

This conversation happened amid Baldwin's critical and popular renaissance in 2014. In April of that year, the New York Live Arts workshops staged a series of exhibits, dialogues, and performances to kick off a "Year of Baldwin" in New York City cosponsored with Columbia University; in June, scholars convened in Montpellier, France, for the fourth biannual Baldwin conference; and in August, 
Baldwin's contemporary admirers celebrated the dedication of James Baldwin Place as a portion of 128th Street in Harlem. Meanwhile, Baldwin scholars geared up for the launch of the James Baldwin Review and the publication of the Cambridge Companion to James Baldwin, both set to be released in 2015.

Conscious of this renewed interest in Baldwin, we posed ourselves questions that would reveal points of intersection-and sometimes friction-in our thinking about privacy as a central fault line in Baldwin Studies:

- How did Baldwin imagine the distinction between public and private in terms of race, gender, sexuality, etc. What sort of privacy claims can or should such a public figure make?

- Given contemporary concerns about the erosion of privacy, on the one hand, and longstanding assertions that the personal is political, what can we learn today from Baldwin's privacy claims? Can privacy be a site of joy or anger, which we may want to protect?

- How do we think about preserving the public legacy of a man whose personal letters and domestic life may not be readily available, including a final home slated for demolition? Is there anything off limits?

The question of privacy is a central pivot in understanding Baldwin. As one of the most important literary and intellectual voices of the twentieth century, Baldwin's appeal has endured across shifting political eras, theoretical schools, and literary sensibilities. Over the past six decades, Baldwin's writing has sometimes fallen briefly out of favor, or some aspects of his work have seemed more urgent or representative than others. What has remained constant is an interest in Baldwin's unmatched ability to navigate the personal and the political to fashion a relentlessly intimate critique of power and America's racial myths. This points to the concept of privacy, though what we mean by the private is always shifting. In fact, Baldwin's work may provide new ways to understand privacy at a moment when it seems most endangered.

The A.S.A. roundtable was a model of the kinds of big thinking and intellectual community that a figure such as Baldwin can engender. Each of the participants are working on book-length studies of Baldwin from various disciplines, methods, eras, sensibilities, and concerns, and each resulting book will be an important contribution to Baldwin Studies. The conversation that ensued among the thirty or so people in the room that day was particularly generative and probing for all. By featuring the opening comments from each scholar in The James Baldwin Review, we hope to establish a national forum to bring together yet more scholars around these questions. Let the conversation continue. 


\section{"If You Can't Be Free, Be a Mystery:" James Baldwin and the (Open) Secret}

My remarks this afternoon constitute my own thinking through of the relationship between reticence and revelation in James Baldwin's public position on his sexual life and, more broadly, in terms of contemporary formulations of black sexualities. I will confess at the outset that, despite my training as a scholar of sexuality, I harbor still a few critical blind spots about the relationship of sexual desire and erotic autonomy to disclosure and display. For someone who is and was raised Muslim, the ethics of sexuality, along with assumptions and aspirations about sexuality's emancipatory promise, depend on a different understanding of the boundaries between the public and private. As I was preparing my remarks, I thought about the final line of Rita Dove's poem, "Canary" that reads: "If you can't be free, be a mystery," which beautifully names a mode of existence and of movement in the world to which I tend to personally adhere. To reduce the violent effects of pathological ascription, those who have been marginalized and minoritized can choose to court opacity, inscrutability, secrecy even. Thus, in thinking about Baldwin's early reticence about his queerness, I am fairly easily persuaded that it accomplished for him two meaningful tasks: first, a refusal of assent to the binaristic taxonomy of sexualities and, second, an attempt to secure for himself-a queerly embodied black man, leading Civil Rights spokesperson, and literary celebrity at mid-century-a space of license, exploration, and pleasure, or, more plainly, a site of privacy. ${ }^{2}$

The spectacular, highly visible, and fantastical-that is, the public-character of embodied blackness grants it a level of iconicity and in Harvey Young's astute formulation "a compulsory visibility." Harvey Young writes: "The black body, whether on the auction block, the American plantation, hanged from a lightpole as part of a lynching ritual, attacked by police dogs within the Civil Rights era, or staged as a 'criminal body' by contemporary law enforcement and judicial systems, is a body that has been forced into the public spotlight and given a compulsory visibility." 3 James Baldwin came of age during the era of Jim Crow. Legal segregation in the South and de facto segregation in the North structured racial discrimination in every arena of civic life and, further, mandated repeated enactments of that discrimination each time a black person appeared in public. Racial segregation and racial terrorism converted every instance of African-American participation in the ordinary, everyday behaviors and movements that characterize civic belonging (purchasing and selling goods; traveling; attending places of work, worship, and learning, etc.) into ritualized iterations of racial subordination and civic exclusion-that is, into repetitive public stagings of racial harm. And, even to this day, the public character of racial overdetermination (working in tandem with a murderous, carceral state) effectively robs racialized persons of what Hortense Spillers recently described as "privacy as a fundamental human right."

Following Spillers and thinking about Baldwin, I pose here a few questions: What is it about the publicness of blackness that creates in others such false and intrusive intimacy? What aspects or practices of the self gather within the domain 
of "the private" in the formulation of privacy as a universal right to which every human has claim? How does desire function as part and parcel of legible blackness, or more specifically of racial fetish, and as a welcome escape from both? And, finally, how might we settle more comfortably with the mystery and the complexity of a human whose acts and inclinations do not necessarily adhere to the logics of language or the schemas of representation? ${ }^{5}$

James Baldwin's influence may be discerned in current critiques of recognition politics, which, by focusing on representation, have overlooked reparative, sociopolitical and material redistribution. ${ }^{6}$ The political goals of recognition and institutional inclusion-that is, treating tokenism as group progress-have failed over the last half-century to produce sustainable, systemic transformation. Baldwin understood the importance of reckoning with power as it inheres and manifests in social conditions rather than in discrete identity categories. In the 1976 essay "The Devil Finds Work," he describes identity not as the static fact of one's existence but as an ongoing and dynamic practice: "Identity would seem to be the garment with which one covers the nakedness of the self: in which case, it is best that the garment be loose, a little like the robes of the desert, through which robes one's nakedness can always be felt, and, sometimes, discerned" (537). ${ }^{7}$ Casting identity as a garment that must be worn loose, Baldwin emphasizes the inevitable negotiation among self, society, and circumstance. Moreover, he locates emancipatory possibility not in social categories bequeathed at birth but in the self-willed labor that constitutes that negotiation.

Sexuality is a crucial site of such negotiation, and one that provides for the self-identified or the embodied black person a usable site of personal safety, indulgence, and volitional self-fashioning. Given the impossibility of totalized refutation, racialized subjects may productively obscure and reroute what our existence has come to signify - and that has been used to justify the many structural and symbolic iterations of anti-otherness that fundamentally undergird sociopolitical and material asymmetry. Because of the intractability of racial difference, with its vexing tendencies to inspire desire and repulsion, exclusion and fixation, sexuality functions, I imagine, for James Baldwin, as I believe it does in black expressive culture in general: as a place of shelter, of pleasure, and of imaginative (re)construction. Despite black histories of sexualized racial conquest and despite the ideations of moral and sexual debauchery that to this day accrue to racial blackness, sexuality constitutes for black subjects a usable space for reflection and transformation. I am not thinking here of sexual acts per se; I am thinking, rather, of the momentary but discrete exercise of individual will, the enactment of pleasure, the political refiguration of racialized identity, and the manifold practices that comprise black aesthetic traditions. Because of the fundamental elusiveness of sexuality (despite historic attempts to define and demarcate it), might it be possible for the racialized subject to find privacy in the refuge of unuttered and unutterable desire?

Aliyyah I. Abdur-Rahman, Brandeis University 


\section{Quiet as It's Kept: Baldwin and the Question of Privacy}

As part of a larger re-examination of how moral questions are posed in literature, I am interested in understanding the moral universe Baldwin has imagined or reimagined over the course of six novels and through his short story collection, plays and poetry. What obligations do human beings (or characters) have to one another and their respective selves in that world? What are the costs and consequences of life and the world if these obligations are not honored or taken seriously?

There are moral consistencies dare I say, structures in Baldwin's imaginative work that offer us a theory of justice that far surpasses that of John Rawls or any political philosopher/thinker in its ability to generate costs, benefits, and identify the place of human emotion, frailty, and vulnerability as they relate to moral ideas and problems. What normative moral discourse has left outside the realm of discursiveness forms the very foundation of Baldwin's moral imagining. Outsiders become insiders, and the disavowed becomes the center.

Concerning the question of privacy, in my reading of Baldwin, the performative figure, the author, I pause on the distinction he makes between the essay as the realm for public examination or discourse and the novel as the stage and technology for addressing the private. Both are available for the personal and political, the infusion of the autobiographical, but the novel is where we can find the more extensive discomfort of dealing with, according to Baldwin, the "private, personal, sexual, emotional." Here, I think it is helpful to recall Toni Morrison's discussion of The Bluest Eye in her Tanner lectures, "Unspeakable Things Unspoken: The Afro-American Presence in American literature," particularly the passages where she inscribes that opening to The Bluest Eye-Quiet as it's kept-with contextualized meaning.

The opening phrase of this sentence, "Quiet as it's kept," had several attractions for me. First, it was a familiar phrase, familiar to me as a child listening to adults; to black women conversing with one another, telling a story, an anecdote, gossip about some one or event within the circle, the family, the neighborhood. The words are conspiratorial. "Shh, don't tell anyone else," and "No one is allowed to know this." It is a secret between us and a secret that is being kept from us. The conspiracy is both held and withheld, exposed and sustained. In some sense it was precisely what the act of writing the book was: the public exposure of a private confidence. In order fully to comprehend the duality of that position, one needs to think of the immediate political climate in which the writing took place, 1965-69, during great social upheaval in the life of black people.

"Great social upheaval in the life of black people." At what point in history has this sentence not been true? When we seize Baldwin's letters, ask about his private life, investigate his sexuality, my question is this: do we fully understand "Quiet as it's kept?" Have we fully understood "great social upheaval in the life of black people?" If we do, then we are better prepared to read Baldwin against 
the Enlightenment, against the narrative of modernity, against master narratives. We will recognize how to read silences, ironies, rupture through a hostile hermeneutics that denies scholarly imperialism.

The figure I read more than Baldwin is the nineteenth-century writer Soren Kierkegaard. The scholars who study Kierkegaard, thanks to the generous support of the Danish government, have access to every manuscript and even the small scraps of paper her wrote on during his career. Scholars have used this to author great studies of his life, his writing - and the work has also been used to examine his less than admirable remarks about gender or what are described as moments of anti-Semitism. I write about Kierkegaard and slavery-a project that poses similar questions and yields answers that differ from the findings of scholars who prefer to focus on Kierkegaard and Heidegger, Kierkegaard and the Internet, and so on. Perhaps we can be said to disagree in our readings of Kierkegaard.

What is remarkable to me is that the leaders of the Kierkegaard Centre welcome all projects, those that praise Kierkegaard and those that expose some problematic nature of his writing, even if they disagree with the approach. In addition to Kierkegaard's philosophy, influence and relation to existentialism, scholars have also explored his sexuality, his relationship to his family, the details surrounding his death, as well as his medical records. People agree, disagree. Above all, the Centre asks that scholars be rigorous and thorough.

I believe this is how we can examine Baldwin, rigorously and thoroughly as the scholars on this panel already do to that rigor and thoroughness, let us add as context, "Quiet as it's kept" and "Great social upheaval in the life of black people.” Baldwin's letters, his private life, questions of privacy can be sorted out in an atmosphere of academic rigorousness that pays attention to and respects the complexities of black life.

Because I have said this privacy question is addressed in Baldwin's imaginative work, I'll end with a memorable passage from Another Country-

The trouble with a secret life is that it is very frequently a secret from the person who lives it and not at all a secret for the people he encounters. He encounters, because he must encounter, those people who see his secrecy before they see anything else, and who drag these secrets out of him; sometimes with more benevolent intent; but, whatever the intent, the moment is awful and the accumulating revelation is an unspeakable anguish. The aim of the dreamer, after all, is merely to go on dreaming and not to be molested by the world. His dreams are his protection against the world. But the aims of life are antithetical to those of the dreamer, and the teeth of the world are sharp. ${ }^{8}$

Nigel Hatton, University of California-Merced 


\section{James Baldwin's Late Style: A Sketch on Privacy}

For too long, a declension narrative obfuscated our understanding and appreciation of James Baldwin's corpus. It went something like: Baldwin started out strong in his early fiction and essays, notably Go Tell It on the Mountain and Notes of a Native Son; peaked in the 1960s with the publication of Another Country and The Fire Next Time; and afterwards lost the qualities that had defined and distinguished his early art. Such a myopic view of Baldwin's oeuvrefocusing exclusively on the author's early to middle career, overlooking the books and essays he wrote from the mid-1970s until his death in 1987, or lumping together the late works in ways that confound any close reader-is now coming undone, as the resurgent scholarship on Baldwin attests. My aim is to steer our attention towards the author's neglected latter writings to illuminate a distinct late style that emerges in a series of books and essays he wrote in the last decade of his life.

Late style, as Edward Said observes, is a generative concept to measure how the work of great artists achieves a new prerogative as they near the end of their lives: "This is the prerogative of late style: it has the power to render disenchantment and pleasure without resolving the contradiction between them. What holds them in tension, as equal forces straining in opposite directions, is the artist's mature subjectivity, stripped of hubris and pomposity, unashamed either of its fallibility or of the modest assurance it has gained as a result of age and exile." Indeed, late style keys our attention to the powerful ways Baldwin's latter writings conjoin desire and disillusionment, and express wisdom hard earned from age and exile. It also helps us to trace the author's changing position on privacy.

A defining feature of Baldwin's late style is that for the first time the author begins to emplot his own queer sexuality in the essay form. One way of delineating the difference between Baldwin's fiction and his essays, between his persona in the novel and his persona in the essay, is by paying close attention to how non-normative sexuality is narrated in each form. Queer sexuality is central in Baldwin's novels but peripheral in the essays, and it's only in his last set of published essays in the 1980s-"The Price of the Ticket," "Freaks and the American Ideal of Manhood," and "To Crush a Serpent"-that he writes explicitly about his own desire for, and past intimate relationships with, other men. Baldwin had broached the question of homosexuality as early as 1949 in the expository essay, "The Preservation of Innocence;" and, in passing, in No Name in the Street (1972) when he sought to counter Eldridge Cleaver's homophobic slurs against him. That said, it's in the mid-1980s that he employs the personal essay to narrate his own sexual coming-of-age. Since a signature of the Baldwin essay is the way it leverages the author's individual experience as text for collective reflection, it's important to examine why, unlike his racial coming-of-age, his sexual awakening doesn't become a central subject of his essays until late in life. 
Why revise a steadfast position, one he held in many interviews, that his sexuality was a private matter that did not merit public discussion? For instance, when asked about it in Sedat Pakay's gem film, James Baldwin: From Another Place, shot in Istanbul in May 1970, Baldwin says: "I don't really know how to answer that question. In the first place, I don't exactly resent it, but I don't feel it's somebody's business whatever goes on in anybody's bedroom. But in my own case I can see that it's a very big issue for a lot of people. I don't know, I have a certain Puritan thing about two things - a certain kind of privacy, which is everybody's right, certainly mine, a certain kind of pride." ${ }^{\prime 0}$ So, then, why does Baldwin breach that privacy towards the end of his life and narrate his own sexuality in the essay form? Not a negligible fact for a writer who transformed that genre-for, it's no exaggeration to say, that we now mark and measure the personal essay before and after James Baldwin. Is there a direct relationship between the timing of these late essays and the fact that Baldwin no longer assumed the same responsibilities of the public intellectual or the Race Man that he did in the 1960s? That he was no longer beholden to the heteronormative trappings of those roles, how might that bear on his sense of privacy? The culture of sexuality also changed dramatically over the course of Baldwin's life, how did that inform his idiom of privacy? How about the rise of black women authors and the way they reclaimed in 1970s and 1980s "the margin as central," as Toni Morrison put it, and centered the body that patriarchy had sidelined-did that have a bearing? And, more generally, in the wake of the Black Power and Black Arts Movement, how did the shift in emphasis from the interracial to the intra-racial or intramural black life inform Baldwin's latter enterprise? These are among the key questions I take up in a book-in-progress titled, "Here Be Saints: James Baldwin's Late Style." The concept of late style I believe can be productive in exploring these questions and ultimately how Baldwin's late works acquire a new temperament, including a new prerogative of privacy.

Dagmawi Woubshet, Cornell University

\section{"The House is Not a Home:" Private Challenges of Preserving James Baldwin's Public Legacy}

Caught in between the public and private personas of the Civil Rights Movement activist and queer black man who lived internationally, James Baldwin is a challenging case study. With no true access to his papers, no preserved sites, or objects, scholars face either his stereotypical representations in the media and public events, or accounts and anecdotes by his friends and acquaintances, many of whom as Maria Diedrich notes, eagerly elide his complexities to create "everybody's Jimmy." "11 
My approach, though mindful of these representations, situates itself in between the imperatives of this writer's literary apparatus-autobiography, autoethnography, and genre experimentation-and material and visual culture narratives arising from the sites he occupied while composing specific works. Part of a book in progress, In the Company of Women: James Baldwin's Lost Decade, this glimpse of the archive and methods with which I have been grappling focuses on Baldwin's house in St. Paul-de-Vence, a village in southern France, where he found a writing haven and held court for numerous famous visitorsJosephine Baker and Nina Simone, Miles Davis, Yves Montand and Simone Signoret among them-during the last sixteen years of his life. Baldwin wrote many of his late works there, including his last novel, Just Above My Head (1979) and several essays which appeared in such popular publications as Architectural Digest and Playboy. These pieces, and the site of his house, which I first investigated in June 2000 and where I returned in June 2014, provide an indispensable context for the last work he kept revising until his death in 1987, the play, The Welcome Table (1987).

Hybridic in terms of genre and its approach to gender, the play is a fitting coda to Baldwin's life-long struggle to free the self from the straightjacket of binary notions of race, sex, and gender. The action of The Welcome Table takes place in a house in Provence much like Baldwin's, and its setting, style, and structure reflect both the new ways of writing drama that Baldwin came to in the 1980s and the influence of women friends who taught him what it was like to be female, black, and queer in the late twentieth-century worlds of Europe and the United States.

My two visits to the house convinced me that the only way to locate Baldwin's late work was to excavate, if you will, what remains of Chez Baldwin despite its gradual erasure, to write into being its material and metaphorical stories as a black queer space that was key to The Welcome Table. ${ }^{12}$ In the essay, "The Site of Memory," Toni Morrison offers advice:

On the basis of some information and a little bit of guesswork you journey to a site to see what remains were left behind and to reconstruct the world that these remains imply. What makes it fiction is the nature of the imaginative act: my reliance on the image-on the remains-in addition to recollection, to yield up a kind of truth. By "image," of course, I don't mean "symbol;" I simply mean "picture" and the feelings that accompany the picture.

In contrast to that Morrison emphasizes, the traditional task of a "trustworthy" literary critic or biographer is to trace the "events of fiction" to some "publically verifiable fact;" it is to excavate the "credibility of the sources of the imagination, not the nature of the imagination."13

Given my dual task of writing up James Baldwin's house and arguing for literature and architecture as inseparable bedfellows in my approach to his house as the site of writing The Welcome Table, my project's demands fall in between 
scholarship and fiction. As a critic and biographer, I appear to be merely a collector of what Morrison deems "publically verifiable fact[s]." At the same time, I insist on the right to claim access to "pictures" and "feelings" inspired by my on-site research and close readings of his works. As Trinh T. Minh-ha reminds us, "writers of color [and immigrants, I'd add] ... are condemned to write only autobiographical works. Living in a double exile-far from the native land and far from the mother tongue-they ... write by memory and ... depend on ... hearsay... The autobiography can thus be said to be an abode in which ... [they] take refuge." 14

While Baldwin fits this description to some degree as a writer rendered homeless by his identity - as Kendall Thomas reminds us, he was driven away from his homeland by both racism and homophobia-he also expands it by demonstrating that building one's abode in language goes hand in hand with establishing writing havens, however temporary, that can accommodate a rare and unique subject, a black queer American who has chosen to dwell in the world. ${ }^{15}$ It is a great loss that his house in St. Paul-de-Vence can serve as such a space only symbolically, only as a memory and reminder of things past.

Magdalena J. Zaborowska, University of Michigan

\section{Toward an Ethics of the "How:" Race, Knowledge, and Representation}

In its 15 September 1955 issue, Jet Magazine published a shocking photograph of Emmett Till's corpse, revealing punctures and lacerations in the flesh that quite literally exposed Till's bodily interiors to viewing audiences. The young, teenaged face, Fred Moten has observed:

was turned inside out, ruptured, exploded, but deeper than that it was opened. As if his face were the truth's condition of possibility, it was opened and revealed. As if revealing his face would open up the revelation of a fundamental truth, his casket was opened, as if revealing the destroyed face would in turn reveal, and therefore cut, the active deferral or ongoing death or unapproachable futurity of justice. ${ }^{16}$

Doubly transformed into embodied signifier, Till's "opened" face operated within at least two economies of "truth." On the one hand, it indexed the force of white supremacy, highlighting its stubborn investment in the maintenance and conservation of a white supremacist social order. Indeed, this ghastly reminder of the distance white supremacy would travel to protect its very being intensified blacks' anxieties around white supremacist violence, and often constrained certain articulations of black political dissent. At the same time, however, this funereal staging of Till's "opened" face enabled activists to project evidence of white supremacist violence to a broad global community. That Till's mother opted to host an open-casket funeral was a particularly effective 
political strategy. The barely recognizable geography of the lad's face gave rise to an international outcry of protest.

An obvious tension moves between these two framings and interpretations of Till's facial interiors. They seem, in fact, to work in opposition. Yet, in both instances, Till's flesh enters into a performative economy of embodied labor. The work of repetition-whether in the form of reproduced media images or the murderers' repetitive infliction of physical violence-helped to both establish and re-elaborate existing relations of racial power.

A part of my current book project grapples with the complexities that arise in such practices of representing black interiors. Broadly, the project examines the relationship between literature and performance during the modern Civil Rights Movement, paying particular attention to the ways in which the movement was acted on the "theatrical stage" as creatively as it was the more familiar sites of embodied activism that dominate histories and memories of the movement: lunch counters and buses, schools and courtrooms, streets and prisons, to offer a partial list. But I dedicate one of the book's chapters to analyzing a historical trafficking in black interiority that has been a mainstay not only of the black freedom struggle, but also of the shaping of Western modernity more broadly-from racialized sexual violence to modern medical experimentation.

Consider, for example, the pivotal 1954 U.S. Supreme Court case, Brown v. Board of Education, in which the attorneys for the N.A.A.C.P. strategically mobilized research findings of black social psychologists-Drs. Mamie and Kenneth Clark - to demonstrate the ways in which segregation wreaked havoc on the psyches-the mental interiors-of black youths. In their now-famous "doll study," the Clarks presented black youths with a choice between visibly white and black dolls; the majority of those tested preferred the former. For the Clarks, and subsequently the Court, this partiality for whiteness signified a damaged black psyche, produced in and through routine practices of white supremacist violence. Believing that segregation cultivated black psychic damage "unlikely ever to be undone," the Court reversed its proverbial endorsement of racial segregation advanced under the banner of its infamous 1896 Plessy V. Ferguson ruling. Like Till, the subjects of the Clarkes' study endured openings of their bodies in order to uncover and project damaged black interiors that were victims of white supremacist violence. As Saidiya Hartman has reminded us, journeys into the space of black interiors have often been pursued with "good" intentions, whether in the form of progressive laws, civil rights photography, or the advancement of scientific knowledge. Yet, the condition of possibility for such explorations has often been a foreclosure of black embodied privacies.

In the aforementioned chapter of my book manuscript, I am especially concerned with the ways that James Baldwin and other black dramatists, such as Alice Childress, Lorraine Hansberry, and Douglas Turner Ward, challenge habits of according black bodies what I call a telescopic instrumentality, especially during campaigns to secure the rights of African-descended peoples. 
These cultural workers, that is to say, probe historical tendencies to frame black bodies-particularly those whose interiors have been ravaged by white supremacist violence - as a lens through which global communities can "see" and "know" white supremacy and the terms of its being. But my broader interests in the politics of race, representation, embodiment, interiority, and knowledge move beyond the pages of my current book project. They are particularly relevant to my budding work on the practices, politics, and ethics of how we engage the archives of black artists like James Baldwin.

Though currently in a conceptual, speculative state, I am curious about the ways in which privacy gets imagined and negotiated in the time and space of black death. While medicine and social science, for example, are governed by extensive and elaborate review boards that consider the ethics both of practice and the production of knowledge, what formal modes of ethical inquiry inform research in the humanities? What are the ethical structures, if any, to which we, researchers in the humanities, are accountable? How do we approach, analyze, and preserve the interior dimensions of James Baldwin's life as he rests in death? What privacies, if any, do we owe to the interior spaces of his psyche, his body, and most recently his home? Finally, as we routinely cross disciplinary boundaries, what are we to make of the research protocols that govern the disciplines into which our critical curiosities routinely lead us? As the material traces of James Baldwin's life of fugitive itinerancy become more accessible to those of us eager to expand our knowledge of one of history's most honest and beautiful trombones, how we know what we know should remain at the forefront of critical inquiry. What I am after, then, is the ethics of the "how."

Julius B. Fleming, Jr., University of Maryland

\section{The Private Life of Resistance}

I am used to writing much longer pieces. Now, I do not say that in order to mark what follows with some sort of asterisk, exempting me from critical scrutiny, but instead to note that however brief these remarks, what I have to say draws on a broader constellation of ideas and yet makes a relatively simple claim: African-American cultural formation, in a word tradition, is nicely characterized as a private life of resistance. Of course, the tradition, as with all traditions, is wholly public and comprised of performances in every aspect of embodied and writerly life, from vocal sound to dance to the novel to theories of poetics and practice. But it is also private, for Baldwin, insofar as the tradition operates as a counter-narrative, often adorned by the elliptical and subversive speech of the vernacular (Bessie Smith's endless gift to the tradition), that gives life to a people in the swirl of death that has so often been the life of the American lifeworld. 
Some reflections, then, in two parts. First, an indulgence, please, as I make a note of my interest in James Baldwin's non-fiction in terms of the larger questions of a book project. Then, second and from that larger interrogative frame, I want to say a word or two on the question of privacy and how it might resonate in that project.

This book, tentatively entitled "So Unimaginable a Price:" Baldwin and the Black Atlantic, offers a treatment of Baldwin's non-fiction in the context of the mid-century black Atlantic moment. That moment is defined in large part by anti-colonial struggle, a struggle that produced some of the most enduring and profound cultural and political theory of the period and after. Issues of language, subjectivity, embodiment, history, memory, and, in the end, questions of what constitutes a sense of "home" compose a revolutionary moment in philosophical thinking. Black Atlantic thinkers confront whiteness, not just as part of the past, but as a ghost of the future, a specter haunting the horizon of the imaginable. This is the effect of colonialism, to make the whole world white and therefore unlivable for Black people. How can we think liberation outside that horizon? What alternatives are possible? In conceiving this moment, the enigma of Baldwin's work in the black Atlantic context is crucial, namely in how that work pushes so hard against the competing articulations of diasporic identity. In short, how Baldwin contests the universality of the colonial paradigm.

The question of privacy is crucial here as well, especially in trying to theorize how Baldwin might complicate the black Atlantic narrative of diaspora. Aimé Césaire's presentation at the 1956 Paris Congrés, treated in such provocative terms in Baldwin's "Princes and Powers," sets the context for this complication. In positing "what legitimizes our meeting here," Césaire describes a two-fold sense of Black solidarity. He writes:

There is a double solidarity among all those who are gathered here: first, a horizontal solidarity, a solidarity created by the colonial or semicolonial or paracolonial situation that has been imposed on us from without. And on the other hand, another solidarity that is vertical, a solidarity in time, which comes from the fact that out of an initial unity, the unity of African civilization, there has been differentiated a whole series of cultures that all owe something to that civilization. ${ }^{17}$

Colonialism binds the diaspora in a shared lived-experience-subjugation, exploitation, particular forms of alienation-but the élan vital of diasporic unity lies in the de-activated, but wholly re-activateable, civilizational force of Africa. Colonialism therefore names a shared sense of loss and the possibility of retrieval, a sort of negative-actuality and nascent potentiality whose time-structure is simultaneously the ancient past and the unprecedented future.

Baldwin's response to this in "Princes and Powers" is profound and moving, appealing, against Césaire (and the thrust of the 1956 Congrés), to a sense of ownership_to a sense that suffering and work earn a right to place, a right older and more deeply rooted than the white supremacist claims to the same, 
and therefore a right that is as much existential as it is moral. This ownership is everything. A right to the land, yes, but also and just as importantly, a right to place. This last twist in "Princes and Powers" is key. What is place? How does space, land, or territory get transformed into a sense of place, even without belonging? Or, perhaps better put, how is place forged as a counter-belonging in a space that by law and custom-by all those swirling violences of anti-Black racism-blocks belonging? Baldwin's account of this place is something akin to the revealing of a secret that has never been secret, yet remains hidden from view. Not quite Du Bois' veil, but certainly nothing like the epic metaphysical force of Césaire's Africa.

Here, I think the notion of privacy is helpful. Colonialism, if I may make a broad statement (the five-to-eight minutes thing), has the feature of making everything public, in the sense that the colonial relation cannot install measure without making that measure explicit and evident. The power of colonialism draws from its hyper-visibility, which, in turn, becomes a total project precisely because the visibility of that power occludes all other possibilities of knowing and being. That is how the white gaze functions as a force of domination: in the public, the measure for everyone. Fanon's Black Skin, White Masks is arguably the best documentation of this equation of visibility and domination; the book shows time and again how the gaze embodies everything and is in everything, from the skin to language to love to the imagination. A total project. Baldwin does a good bit in "Princes and Powers" to mark the African-American experience as different, never quite colonial enough to warrant full membership in Césaire's sequence: colonial, semi-colonial, or para-colonial. The difference is not so much a difference in kinds of white people; the white gaze is plenty troubling and the source of plenty violence in Baldwin's work, for sure. The difference is more about attuning the writerly and thinking gaze to what is not visible to the white gaze, and therefore not made meaningful by it. In particular, I am thinking of this passage from "Many Thousands Gone," in which Baldwin sets out the parameters of his thinking about Black people and establishes that important difference between his work and the work of anti-colonial struggle we find in Césaire and Fanon, but also Wright's early fiction. He writes:

What this means for [Native Son] is that a necessary dimension has been cut away; this dimension being the relationship that Negroes bear to one another, that depth of involvement and unspoken recognition of shared experience which creates a way of life ... [Wright's novel] creates its climate of anarchy and unmotivated and unapprehended disaster; and it is this climate, common to most Negro protest novels, which has led us all to believe that in Negro life there exists no tradition, no field of manners, no possibility of ritual or intercourse ... For a tradition expresses, after all, nothing more than the long and painful experience of a people. ${ }^{18}$

In many ways, we could say that this passage completes the struggle to articulate what Baldwin, at the close of "Encounter on the Seine," simply calls 
birthright-the right to the land of one's birth. It is surely that. With the word tradition, Baldwin names the continuity of a people, a continuity of pain, of course, yet also the continuity of experience, which we know is broader and deeper than what white people have done to Black people. Something already outside the power of the white gaze. But it also pushes against the publicity of a diasporic unity derived from the horizontal solidarity of shared colonial experience. In part, this is simply another version of how the United States does not fall easily, if at all, under the rubric of coloniality. The frame of "privacy," however, suggests another way of reading this passage, namely, locating a sense of how the "relationship Negroes bear to one another" is a kind of cultural publicness rooted in a kind of historical privacy - a way of life forged outside of what mid-century black Atlantic theorists name as colonialism and place under the rubric of the white gaze as a total project. Tradition is here a sense of relation outside the white gaze that constructs the complexity of the Black gaze directed to itself, exchanging between Black people, and with the effect (and affect) of making a whole world not just as resistance and refusal, but as a way of life, a shared experience in private, while at the same time being wholly public in the formation of a cultural tradition.

Privacy, then, might function as another name for the epistemological difference Baldwin needs to mark an important distance from the colonial experience. And in that difference and distance, Baldwin is able to clear the space for thinking one of the great enigmas of his work: home as counter-belonging and counterbelonging as home. In that counter-belonging, from that space of a claimed home, a place in the world, a resistance untouched and, perhaps, untouchable.

John E. Drabinski, Amherst College

\section{Notes}

1 Rita Dove, "Canary," in Grace Notes (New York, Norton, 1989).

2 Though framed somewhat differently, my thinking here follows an important intervention in queer studies and politics. The critique of "coming out" as a progressivist narrative of modern subjectivity and possessive individualism has been explored thoroughly in queer of color scholarship. Noted theorists include Marlon Ross, "Beyond the Closet as a Raceless Paradigm," in E. Patrick Johnson and Mae G. Henderson (eds.), Black Queer Studies: A Critical Anthology (Durham, N.C., Duke University Press, 2005), pp. 161-89; Jasbir Puar, Terrorist Assemblages: Homonationalism in Queer Times (Durham, Duke University Press, 2007); and Jeffrey McCune, Sexual Discretion: Black Masculinity and the Politics of Passing (Chicago, University of Chicago Press, 2014).

3 Harvey Young, Embodying Black Experience: Stillness, Critical Memory, and the Black Body (Ann Arbor, University of Michigan Press, 2010), p. 12.

4 Hortense Spillers, "Women and the Early Republics: Revolution, Sentiment, and Sorrow," Harvard University, Hutchins Center, Cambridge, M.A., 14 October 2014, W. E. B. Du Bois Lecture. 
5 These are questions that I pose and take up in my book-length study, Against the Closet: Black Political Longing and the Erotics of Race (Durham, Duke University Press, 2012).

6 For excellent, in-depth analyses of the limits of recognition politics, see Jodi Melamed's Represent and Destroy: Rationalizing Violence in the New Racial Capitalism (Minneapolis, University of Minnesota Press, 2011); Roderick Ferguson's The Reorder of Things: The University and Its Pedagogies of Minority Difference (Minneapolis, University of Minnesota Press, 2012); and Sara Ahmed's On Being Included: Racism and Diversity and Institutional Life (Durham, N.C., Duke University Press, 2012).

7 James Baldwin, “The Devil Finds Work," (1976), in The Price of the Ticket: Collected Nonfiction, 1948-1985 (New York, St. Martin's, 1985), pp. 557-636.

8 James Baldwin, Another Country (1960), (New York, Vintage, 1993), p. 199.

9 Edward Said, On Late Style (New York, Pantheon, 2006), p. 148.

10 Sedat Pakay, Dir., James Baldwin: From Another Place (New York, Hudson Film Works, 2007).

11 Maria Diedrich, "James A. Baldwin-Obituaries for a Black Ishmael," in Jakob Köllhofer (ed.), James Baldwin: His Place in American Literary History and His Reception in Europe (Frankfurt am Main, Peter Lang, 1991), p. 131.

12 I have written at length about Baldwin as a black queer writer in my last book, and given the proliferation of excellent recent criticism on this writer, will refrain from repeating the definitions here. See Magdalena Zaborowska, James Baldwin's Turkish Decade: Erotics of Exile (Durham, N.C., Duke University Press, 2009).

13 Toni Morrison, "The Site of Memory," in William Zinsser (ed.), Inventing the Truth: The Art and Craft of Memoir (Boston, New York, Houghton Mifflin, 1995), pp. 183-200, 192-3.

14 Trinh T. Minh-Ha, "Other Than Myself/My Other Self," in George Robertson (ed.), Travellers' Tales: Narratives of Home and Displacement (London, Routledge, 1994), pp. 8-26, 9.

15 This analysis has broader repercussions that I have no room to elaborate. For example, it might open up a reading of Amy Kaplan's "Manifest Domesticity," American Literature, 70:3 (September 1998), pp. 581-606, as yet another instance of representing national American domesticity as excluding blacks and queers. See also Janet Floyd and Inga Bryden, Domestic Space: Reading the Nineteenth-Century Interior (Manchester, Manchester University Press, 1999); and Irene Cieraad, At Home: An Anthropology of Domestic Space (Syracuse, Syracuse University Press, 1999).

16 Fred Moten, In the Break: The Aesthetics of the Black Radical Tradition (Minneapolis, University of Minnesota Press, 2003), pp. 198-9.

17 Aimé Césaire, "Culture and Colonization," Trans. Brent Hayes Edwards, Social Text, 103 (2010), pp. 129-30.

18 James Baldwin, "Many Thousands Gone," (1955), in The Price of the Ticket: Collected Nonfiction, 1948-1985 (New York, St. Martin’s, 1985), pp. 65-78, 72-3.

\section{Works Cited}

Abdur-Rahman, Aliyyah I., Against the Closet: Black Political Longing and the Erotics of Race (Durham, N.C., Duke University Press, 2012).

Ahmed, Sara, On Being Included: Racism and Diversity and Institutional Life (Durham, N.C., Duke University Press, 2012).

Baldwin, James, The Price of the Ticket: Collected Nonfiction, 1948-85 (New York, St. Martin's, 1985). 
Another Country, (1960) (New York, Vintage, 1993).

Césaire, Aimé, "Culture and Colonization," Trans. Brent Hayes Edwards, Social Text, 103 (2010), pp. 129-30.

Cieraad, Irene, At Home: An Anthropology of Domestic Space (Syracuse, Syracuse University Press, 1999).

Diedrich, Maria, "James A. Baldwin-Obituaries for a Black Ishmael," in Köllhofer, Jakob (ed.), James Baldwin: His Place in American Literary History and His Reception in Europe (Frankfurt am Main, Peter Lang, 1991), pp. 129-40.

Ferguson, Roderick, The Reorder of Things: The University and Its Pedagogies of Minority Difference (Minneapolis, University of Minnesota Press, 2012).

Floyd, Janet and Bryden, Inga, Domestic Space: Reading the Nineteenth-Century Interior (Manchester, New York, Manchester University Press, St. Martin's Press, 1999).

McCune, Jeffrey, Sexual Discretion: Black Masculinity and the Politics of Passing (Chicago, University of Chicago Press, 2014).

Melamed, Jodi, Represent and Destroy: Rationalizing Violence in the New Racial Capitalism (Minneapolis, University of Minnesota Press, 2011).

Morrison, Toni, "The Site of Memory," in William Zinsser (ed.), Inventing the Truth: The Art and Craft of Memoir (Boston, New York, Houghton Mifflin, 1995), pp. 92-3.

Moten, Fred, In the Break: The Aesthetics of the Black Radical Tradition (Minneapolis, University of Minnesota Press, 2003).

Pakay, Sedat, Dir., James Baldwin: From Another Place (New York, Hudson Film Works, 2007).

Puar, Jasbir, Terrorist Assemblages: Homonationalism in Queer Times (Durham, N.C., Duke University Press, 2007).

Ross, Marlon, "Beyond the Closet as a Raceless Paradigm," in E. Patrick Johnson and Mae G. Henderson (eds.), Black Queer Studies: A Critical Anthology (Durham, N.C., Duke University Press, 2005), pp. 161-89.

Spillers, Hortense, "Women and the Early Republics: Revolution, Sentiment, and Sorrow," Harvard University, Hutchins Center, Cambridge, M.A., 14 October 2014. W. E. B. Du Bois Lecture.

Trinh, T. Minh-ha, "Other Than Myself/My Other Self," in Robertson, George (ed.), Travellers' Tales: Narratives of Home and Displacement (London, Routledge, 1994).

Woubshet, Dagmawi, Calendar of Loss: Race, Sexuality, and Mourning in the Early Era of AIDS (Baltimore, Johns Hopkins, 2015).

Young, Harvey, Embodying Black Experience: Stillness, Critical Memory, and the Black Body (Ann Arbor, University of Michigan Press, 2010).

Zaborowska, Magdalena, James Baldwin's Turkish Decade: The Erotics of Exile (Durham, N.C., Duke University Press, 2009).

\section{Contributor's Biography}

Brian Norman is Associate Professor of English at Loyola University Maryland where he currently serves as Associate Vice President for Faculty Affairs and Diversity. His books include Dead Women Talking: Figures of Injustice in American Literature (Johns Hopkins, 2013), Neo-Segregation Narratives: Jim Crow in Post-Civil Rights American Literature (University of Georgia, 2010), and The American Protest Essay and National Belonging (SUNY Press, 2007). His work on Baldwin also appears in The Cambridge Companion to James Baldwin (2015), and numerous journals. 